\title{
Choice of road building technology - statistic analyses with the use of the Hellwig method
}

\author{
Izabela Skrzypczak ${ }^{1, *}$, Wojciech Radwański ${ }^{2}$, Tomasz Pytlowany ${ }^{2}$ \\ ${ }^{1}$ Rzeszow University of Technology, Aleja Powstancow Warszawy 12, Rzeszów, Poland \\ ${ }^{2}$ PWSZ Krosno, ul. Rynek 1, Krosno, Poland
}

\begin{abstract}
There are two technologies for road construction, e.g. an asphalt one and a concrete one, that exist in the market of road infrastructure at the moment and they both have their advantages and disadvantages [prof Jan Deja of Krakow Mining Academy, Cathedral of Building Materials Technology].The advantage of concrete pavement consists of the fact that it doesn't require bigger financial expenditures within $10-20$ years of exploitation (provided that necessary pavement maintenance treatments are carried out). In the case of asphalt pavement it is necessary to mill the wear off layer of the road already after 6-7 years. It leads to the question: which of these technologies should be chosen, which is better? The work hereby carries on analyses concerning a comparison of the technologies for road constructions; the asphalt one and the concrete one. Based on the analyses carried out with the use of the Hellwig method it was found that the achieved values of synthetic meters for asphalt and concrete pavements are close to each other, which may indicate that both technologies are comparable within the sectors taken for analyses in relation to accepted technological-technical and usability features.
\end{abstract}

\section{Roads in Poland, as viewed by the law, are divided into public roads and internal roads}

A public road is a road included in one of the following categories: community road, district road, provincial road and state road. The length of public roads (at the end of 2016, as shown by Statistics Poland GUS [1, 4]) is $420236.10 \mathrm{~km}$. Out of these, $400848.0 \mathrm{~km}$ (i.e. 95,4\%) are administered by territorial self-government units General Director for National Roads and Motorways, $28920.40 \mathrm{~km}$ - by the provincial administration, 124 $944.60 \mathrm{~km}$ - by the district administration and 264983.0 by the community selfgovernment, i.e. chief officer (mayor). Within the borders of bigger towns (municipal district type units) all public roads, except motorways and express roads are administered by a town's mayor.

\footnotetext{
* Corresponding author: izas@prz.edu.pl
} 
Their duties include:

- preparation of projects for road network development plans and projects of plans for financing the building, re-building, repair, maintenance and protection of both the roads and road engineering objects,

- performing investment functions,

- keeping a record of roads, working out information about public roads and sending them to the General Director for National Roads and Motorways,

- carrying on periodical control of the condition of roads and road engineering objects with regard to their influence on the security of traffic, including the verification of features and pointing out defects which require either corrective actions or maintenance work because of the security of the road traffic.

- analyses of the influence of road work and safety of road traffic,

- issuing permission for lane occupation and exits from roads, as well as collecting tolls and fines.

\section{Categories and classes of roads}

The road category is connected with its function in a road network in Poland. The Bill of Public Roads [2] distinguishes the following road categories: state roads, provincial roads, district roads and community roads. A road included in one of these categories, in the understanding of Bill [2] of Public Roads, must meet the technical and usability requirements determined for the following classes:

- State road - A (motorway), S (express road) or GP (main road for accelerated traffic),

- Provincial road - GP (main road for accelerated traffic) or G (main),

- District road - GP (main road for accelerated traffic), G 9 main) or Z (collect),

- Community road - GP (main for accelerated traffic), G (main), Z (toll), 1 (local) or D (access roads).

The class of road determinesthe technical and usability requirements. The decree of the Minister of Infrastructure of March 2, 1999 concerning technical conditions to be met by public roads and their location (Dz, U. No 43, pos. 430, with later amendments) introduces the division of roads into the following classes: motorways, express roads, main roads for accelerated traffic, main roads, toll roads, local roads and access roads.

\section{Financing of roads}

Assignments concerning road building, re-building, repair, maintenance, protection and administration and financed by:

- Minister responsible for road transport via General Director for National Roads and Motorways in relation to state roads,

- Provincial self-government administrator in relation to province roads,

- District administrator in relation to district roads,

- Community administrator in relation to community roads.

Within the borders of bigger towns, assignments connected with financing road building, re-building, repair, maintenance, protection and the administration of public roads are paid out of the budgets of these towns. The financing of building, re-building, repair, administration and the protection of private roads is done from the money of their administrators [3, 4]. At present, the General Director for National Roads and Motorways plans to build about $860 \mathrm{~km}$ of roads with concrete technology until the year 2020. In 7 years the share of concrete in fast road networks will increase from $18 \%$ to almost $27 \%$ [4]. 


\section{Road building technologies}

Nowadays, two road building technologies exist in the road infrastructure market: an asphalt one and a concrete one. They are both necessary, and each of them has its advantages and disadvantages [5-15]. The advantage of a concrete structure lies in the fact that within $10-20$ years of exploitation it will not require large financial expenditures (providing that necessary surface maintenance is carried out). In asphalt structures, milling of the wear off layer is already necessary after 6-7 years [5 -15]. This leads to the question: which technology to choose, which one is better?

\section{Comparative analyses of road building technologies - Hellwig's method}

The article presents the comparative analyses of two road building technologies, an asphalt one and a concrete one. It is assumed that all variables: technological-technical - usable ones, statistically are of the same importance and can positively or negatively influence the choice of road pavement technology. For the calculations, Hellwig's modified synthetic meter of development was used [27, 28]. In accordance with Table 1 and Table 2, the divisions and features important for the choice of road building technology were determined and Euclidean distances for features in divisions were calculated as well as meters for individual divisions and synthetic meters for both technologies .

Five groups - thematic divisions were determined (table 1).

Table 1. Divisions for road building technologies.

\begin{tabular}{|c|c|}
\hline No. & Feature \\
\hline 1 & Building costss per $1 \mathrm{~m}^{2}$ \\
\hline 2 & Maintenance cost per $1 \mathrm{~m}^{2}$ \\
\hline 3 & Usability features \\
\hline 4 & Environmental protection \\
\hline 5 & Investment process \\
\hline
\end{tabular}

Table 2. Defined features for individual divisions [16-26].

\begin{tabular}{|c|c|c|c|c|c|}
\hline No. & Feature & Unit & $\begin{array}{l}\text { Bituminous } \\
\text { pavement }\end{array}$ & $\begin{array}{l}\text { Concrete } \\
\text { pavement }\end{array}$ & $\begin{array}{l}Z \text { max } / \\
Z \text { min }\end{array}$ \\
\hline \multicolumn{6}{|c|}{ Building costs per $1 \mathrm{~m}^{2}$} \\
\hline 1 & KR1 & $\mathrm{PLN} / \mathrm{m}^{2}$ & 169,17 & 177,39 & 169,17 \\
\hline 2 & KR2 & $\mathrm{PLN} / \mathrm{m}^{2}$ & 204,54 & 189,79 & 189,79 \\
\hline 3 & KR3 & $\mathrm{PLN} / \mathrm{m}^{2}$ & 249,14 & 266,84 & 249,14 \\
\hline 4 & KR4 & $\mathrm{PLN} / \mathrm{m}^{2}$ & 288,92 & 278,69 & 278,69 \\
\hline 5 & KR5 & $\mathrm{PLN} / \mathrm{m}^{2}$ & 319,27 & 302,39 & 302,39 \\
\hline 6 & KR6 & $\mathrm{PLN} / \mathrm{m}^{2}$ & 346,62 & 316,96 & 316,96 \\
\hline \multicolumn{6}{|c|}{ Maintenance costs per $1 \mathrm{~m}^{2}$} \\
\hline 1 & KR1 & $\mathrm{PLN} / \mathrm{m}^{2}$ & 533,28 & 370,00 & 370,00 \\
\hline 2 & KR2 & $\mathrm{PLN} / \mathrm{m}^{2}$ & 653,10 & 396,91 & 396,91 \\
\hline 3 & KR3 & $\mathrm{PLN} / \mathrm{m}^{2}$ & 707,70 & 481,41 & 481,41 \\
\hline 4 & KR4 & $\mathrm{PLN} / \mathrm{m}^{2}$ & 764,12 & 516,31 & 516,31 \\
\hline
\end{tabular}




\begin{tabular}{|c|c|c|c|c|c|}
\hline 5 & KR5 & $\mathrm{PLN} / \mathrm{m}^{2}$ & 810,88 & 570,55 & 570,55 \\
\hline 6 & KR6 & $\mathrm{PLN} / \mathrm{m}^{2}$ & 854,54 & 605,46 & 605,46 \\
\hline \multicolumn{6}{|c|}{ Usable features } \\
\hline 1 & Longitudinal evenness & & 1 & 0,6 & 1 \\
\hline 2 & Furrowing & & 0,1 & 1 & 1 \\
\hline \multirow[t]{3}{*}{3} & Anti-slip properties & & & & \\
\hline & Motorways & $\begin{array}{l}\text { Conclusive } \\
\text { factor of friction }\end{array}$ & 0,39 & 0,51 & 0,51 \\
\hline & State roads & $\begin{array}{l}\text { Conclusive } \\
\text { factor of friction }\end{array}$ & 0,44 & 0,47 & 0,47 \\
\hline \multirow[t]{9}{*}{4} & Noise [21] & average & 10,20 & 10,23 & 10,201 \\
\hline & Motorways & & & & \\
\hline & $50 \mathrm{~km} / \mathrm{h}$ & Index CPX & 92,8 & 90,1 & 90,1 \\
\hline & $80 \mathrm{~km} / \mathrm{h}$ & Index CPX & 100,1 & 97,4 & 97,4 \\
\hline & $110 \mathrm{~km} / \mathrm{h}$ & Index CPX & 104,6 & 102,4 & 102,4 \\
\hline & State roads & & & & \\
\hline & $50 \mathrm{~km} / \mathrm{h}$ & Index CPX & 90,4 & 92,1 & 90,4 \\
\hline & $80 \mathrm{~km} / \mathrm{h}$ & Index CPX & 97,8 & 100 & 97,8 \\
\hline & $110 \mathrm{~km} / \mathrm{h}$ & Index CPX & 102,5 & 104,6 & 102,5 \\
\hline \multirow[t]{4}{*}{5} & Colour of pavement & & & & \\
\hline & Visibility & & 0,7 & 1 & 1 \\
\hline & Surface heating & Degrees C & 46,97 & 36,08 & 36,08 \\
\hline & & & 2,13 & 2,77 & 2,13 \\
\hline 6 & $\begin{array}{l}\text { Resistance to permanent } \\
\text { deformation }\end{array}$ & & 0,7 & 1 & 0,7 \\
\hline \multirow[t]{3}{*}{7} & $\begin{array}{l}\text { Breaking distance at } \\
100 \mathrm{~km} / \mathrm{h}\end{array}$ & average $[\mathrm{m}]$ & 1,20 & 1,38 & 1,20 \\
\hline & Wet surface & $\mathrm{m}$ & 109 & 96 & 96 \\
\hline & Dry surface & $\mathrm{m}$ & 58 & 49 & 49 \\
\hline \multicolumn{6}{|c|}{ Environmental protection } \\
\hline \multirow[t]{5}{*}{1} & Emission of $\mathrm{CO}_{2}$ & & 11,3 & 2,56 & 2,56 \\
\hline & $\begin{array}{l}\text { Emission of } \mathrm{CO}_{2} \text { From } \\
\text { asphalt and concrete } \\
\text { production (kg of } \\
\left.\mathrm{CO}_{2} / \text { ton }\right)[17]\end{array}$ & $\mathrm{kg} \mathrm{CO}_{2} / \mathrm{t}$ & 27,4 & 694 & 27,4 \\
\hline & $\begin{array}{l}\text { Emission of } \mathrm{CO}_{2} \text { from } \\
\text { production of } 1 \mathrm{t} \text { of mineral- } \\
\text { asphalt mixture and } 1 \mathrm{t} \text { of } \\
\text { concrete }\left(\mathrm{kg} \text { of } \mathrm{CO}_{2} / \mathrm{t}\right)[18]\end{array}$ & $\mathrm{kg} \mathrm{CO}_{2} / \mathrm{t}$ & 10,3 & 107,3 & 10,3 \\
\hline & $\begin{array}{l}\text { Emission of } \mathrm{CO}_{2} \text { from } \\
\text { building } 1 \mathrm{~km} \text { of asphalt and } \\
\text { concrete motorway (kg of } \\
\left.\mathrm{CO}_{2} / \mathrm{km}\right)[20]\end{array}$ & $\mathrm{kg} \mathrm{CO} / \mathrm{km}$ & 347 & 1497 & 347 \\
\hline & $\begin{array}{l}\text { Emission of } \mathrm{CO}_{2} \text { from } \\
\text { maintenance of } 1 \mathrm{~km} \text { of } \\
\text { asphalt and concrete }\end{array}$ & $\mathrm{kg} \mathrm{CO}_{2} / \mathrm{km}$ & 500 & 1610 & 500 \\
\hline
\end{tabular}




\begin{tabular}{|c|c|c|c|c|c|}
\hline & $\begin{array}{l}\text { motorway }(\mathrm{kg} \text { of } \\
\left.\mathrm{CO}_{2} / \mathrm{km}\right)[20]\end{array}$ & & & & \\
\hline \multirow[t]{6}{*}{2} & $\begin{array}{l}\text { Index of influence of } \\
\text { building } 1 \mathrm{~km} \text { of motorway } \\
\text { on the environment }\end{array}$ & & 5,81 & 3,61 & 3,61 \\
\hline & $\begin{array}{l}\text { Greenhouse effect potential } \\
\text { ( GWP) [19] }\end{array}$ & $\begin{array}{l}\text { [ } \mathrm{kg} \text { of } \mathrm{CO}_{2} \\
\text { equivalent] }\end{array}$ & 1712501,5 & 2765765 & 2765765 \\
\hline & $\begin{array}{l}\text { Stratospheric ozone layer } \\
\text { deterioration potential (ODP) } \\
\text { [19] }\end{array}$ & $\begin{array}{l}\text { [kg of CFC-11 } \\
\text { equivalent] }\end{array}$ & 0,395 & 0,13 & 0,13 \\
\hline & $\begin{array}{l}\text { Photo oxidant synthesis } \\
\text { potential (POCP) [19] }\end{array}$ & $\begin{array}{l}{\left[\mathrm{kg} \text { of } \mathrm{C}_{2} \mathrm{H}_{4}\right.} \\
\text { equivalent }]\end{array}$ & 422 & 384,5 & 384,5 \\
\hline & $\begin{array}{l}\text { Acidification - potential } \\
\text { (AP) [19] }\end{array}$ & $\begin{array}{l}{\left[\mathrm{kg} \text { of } \mathrm{SO}_{2}\right.} \\
\text { equivalent }]\end{array}$ & 8353,5 & 6426 & 6426 \\
\hline & $\begin{array}{l}\text { Eutrophication - potential } \\
\text { (EP) [19] }\end{array}$ & {$\left[\mathrm{kg} \mathrm{PO}_{3-4}\right]$} & 1248 & 1092 & 1092 \\
\hline \multirow[t]{6}{*}{3} & $\begin{array}{l}\text { Index of influence on the } \\
\text { repair and exploitation of } \\
1 \mathrm{~km} \text { of motorway on the } \\
\text { environment }\end{array}$ & & 5,81 & 3,61 & 3,61 \\
\hline & $\begin{array}{l}\text { Greenhouse effect potential ( } \\
\text { GWP) [19] }\end{array}$ & $\begin{array}{l}{\left[\mathrm{kg} \text { of } \mathrm{CO}_{2}\right.} \\
\text { equivalent] }\end{array}$ & 996135 & 62245,5 & 62245,5 \\
\hline & $\begin{array}{l}\text { Stratospheric ozone layer } \\
\text { deterioration potential (ODP) } \\
{[19]}\end{array}$ & $\begin{array}{l}\text { [kg of CFC-11 } \\
\text { equivalent }]\end{array}$ & 0,225 & 0,01 & 0,01 \\
\hline & $\begin{array}{l}\text { Photo oxidant synthesis } \\
\text { potential (POCP) }\end{array}$ & $\begin{array}{l}\text { [kg of } \mathrm{C}_{2} \mathrm{H}_{4} \\
\text { equivalent] }\end{array}$ & 294 & 46 & 46 \\
\hline & $\begin{array}{l}\text { Acidification - potential } \\
\text { (AP) [19] }\end{array}$ & $\begin{array}{l}{\left[\mathrm{kg} \text { of } \mathrm{SO}_{2}\right.} \\
\text { equivalent }]\end{array}$ & 5638,5 & 267,5 & 267,5 \\
\hline & $\begin{array}{l}\text { Eutrophication - potential } \\
\text { (EP) [19] }\end{array}$ & [kg PO3-4] & 743,5 & 36,5 & 36,5 \\
\hline \multicolumn{6}{|c|}{ Investment process } \\
\hline \multirow[t]{3}{*}{1} & Stage of design & & & & \\
\hline & $\begin{array}{l}\text { Knowledge of the design } \\
\text { engineers }\end{array}$ & & 1 & 0,8 & 0,8 \\
\hline & $\begin{array}{l}\text { Experience of the design } \\
\text { engineers }\end{array}$ & & 1 & 0,1 & 0,1 \\
\hline \multirow[t]{3}{*}{2} & Stage of building & & & & \\
\hline & $\begin{array}{l}\text { Number of offers - big } \\
\text { contracts }\end{array}$ & number of offers & 28 & 26 & 26 \\
\hline & $\begin{array}{l}\text { Number of offers - local } \\
\text { market small contracts }\end{array}$ & number of offers & 5 & 2 & 2 \\
\hline
\end{tabular}


Calculations were made based on the following algorithm [27, 28]:

- Based on the matrix of standardized in-coming data for all analyzed features, in each division a model object was appointed having coordinates (standardized changeable values) in accordance with (1):

$$
\mathbf{O}_{0}=\left\lfloor z_{o j}\right\rfloor, \quad j=1,2, \ldots, m .
$$

- Coordinates of the model object for each feature in each division was determined based on the following formulation (2):

$$
z_{o j}=\left\{\begin{array}{l}
\max _{i}\left\{z_{i j}\right\} \mathrm{dla} z_{j}^{S} \\
\min _{i}\left\{z_{i j}\right\} \mathrm{dla} z_{j}^{D}
\end{array}\right.
$$

$$
j=1,2, \ldots, m \text {. }
$$

- For each division its distance to model object was calculated based on Euclidean metric as follows (3):

$$
d_{i 0}=\left[\sum_{j=1}^{m}\left(z_{i j}-z_{0 j}\right)^{2}\right]^{\frac{1}{2}},
$$

$$
i=1,2, \ldots, m
$$

- Synthetic measures for individual divisions were calculated according to formulation (4):

$$
s_{i}=1-\frac{d_{i 0}}{d_{0}}, \quad i=1,2, \ldots, m
$$

Where:

$$
d_{0}=\bar{d}_{0}+2 R\left(d_{0}\right)
$$

And:

$$
\bar{d}_{0}=\frac{1}{n} \sum_{i=1}^{n} d_{i 0} ; \quad R\left(d_{0}\right)=d_{\max }-d_{\min }
$$

The standardization of features (Table 3) was the introductory phase which enables obtaining total multi-criteria assessment of each considered division

Table 3. Standardized features.

\begin{tabular}{|c|c|c|c|}
\hline No. & Feature & Bituminous pavement & Concrete pavement \\
\hline 1 & Building costs per $1 \mathrm{~m}^{2}$ & 0,43 & 0,71 \\
\hline 2 & Maintenance costs per $1 \mathrm{~m}^{2}$ & 0,60 & 1,00 \\
\hline 3 & Usable features & 0,16 & 0,27 \\
\hline 4 & Environmental protection & 0,60 & 1,00 \\
\hline 5 & Investment process & 1,00 & 0,60 \\
\hline
\end{tabular}

- Synthetic meters for both technologies were obtained by the aggregation of measures within each division for the analyzed technology. The value of the synthetic meter is 
a value of the geometric average of individual synthetic measures calculated for all analyzed divisions (formulation 7, Table 4):

$$
M_{i}=\sqrt[n]{\bigcup_{i=1}^{n} s_{i j}} \quad(i=1, \ldots, 5 \text { and } i=1, \ldots, 5)
$$

Measure M1 takes a value from the interval $[0 ; 1]$. The nearer a given object is to the model, the higher these values are.

Table 4. Synthetic meters for individual types of pavement.

\begin{tabular}{|c|c|c|}
\hline No. & Pavement & Synthetic meter for pavement \\
\hline 1 & Bituminous & 0,48 \\
\hline 2 & Concrete & 0,49 \\
\hline
\end{tabular}

Based on the analyses made with the use of the Hellwig method, it can be said that the obtained values of synthetic meters for asphalt and concrete pavements are quite close, which indicates that the technologies within the divisions taken for analyses in relation to the features technological- technical-usable ones are comparable.

\section{Summary}

When choosing a road building technology one cannot be limited to building costs alone, but it is necessary to also consider the costs of maintenance and exploitation some 30-40 years later. The main purpose when choosing the road building technology is to build the roads of such a quality that would enable their long time exploitation and usage. Based on the analyses made with the use of the Hellwig method, it is possible to state that both technologies, the asphalt one and the concrete one can be competitive since it leads to their progress and development. Considering the growth of traffic on the roads, concrete can be perceived as a technical and economic alternative to asphalt structures, which is confirmed by presented analyses.

\section{References}

1. Główny Urząd Statystyczny

2. Ustawa o drogach publicznych

3. Rozporządzenie Ministra Transportu i Gospodarki Morskiej ( 1999)

4. E. Ołdakowska, Materiały budowlane 3, pp. 34-35 (2018)

5. A. Szydło, P. Mackiewicz, Ed. Polski Cement (2005)

6. J. Deja, P. Kijowski, https://edroga.pl/drogi-i-mosty/drogi-betonowe-doswiadczenia-zbudowy-i-eksploatacji-cz-ii-22062301/all-pages

7. http://mib.gov.pl/2-RodzajedrogwPolsce.htm\#

8. Plantmix Asphalt Industry of Kentucky (PAIKY)

9. Ch. Milachowski, T. Stengel, Ch. Gehlen, EUPAVE (2011)

10. Asphalt Pavement Alliance

11. M. Gruszczyński, Przegląd Budowlany, 1 (2016)

12. P. Woyciechowski, K. Harat, Construction Technology Architecture, (2012) 
13. M. Senderski, Construction Engineer, 4 (2015)

14. Frost Durability of Roller Compacted Pavements, Portland Cement Association (2004)

15. Production of Roller Compacted Concrete, Portland Cement Association (2008)

16. R. Miller, Compaction of Roller-Compacted Concrete (2000)

17. American Concrete Institute, Farmington Hills (2004)

18. General Technical Specifications, GDDKiA (2013)

19. L. Czarnecki, P. Woyciechowski, G. Adamczewski, KSCE Journal of Civil Engineering, 22(2), 755-764 (2018)

20. L. Czarnecki, P. Woyciechowski, ACI Materials Journal, 109(3), 275-282 (2012)

21. M. Dobiszewska, Journal of Materials Education, 39(5-6), 133-156 (2017)

22. A. Beycioglu, A. Gultekin, H. Aruntas, Y. Huseyin et al., 20(2), 247-255 (2017)

23. Konkol J., Prokopski G., IMAGE Analysis \& Stereology, 30(2), 89-100 (2011)

24. Z. Manko, Jakiel P. Nordic Steel Construction Conference '95, Proceedings, Vol. 1 and 2, pp 445-452 (1995)

25. L. Sleczka, Recent progress in steel and composite structures, pp. 457-462 ( 2016)

26. M. Sztubecka, A. Bujarkiewicz, J. Sztubecki, Civil and Environmental Engineering Reports, 23(4), 137-144 (2016)

27. W. Pluta, Wielowymiarowa analiza porównawcza w modelowaniu ekonometrycznym, PWN (1986)

28. P. Len, G. Oleniacz, I. Skrzypczak, Izabela; et al., SGEM 2016, Vol. II Book Series: International Multidisciplinary Scientific, GeoConference-SGEM, 617-624 (2016) 